\title{
北半球高空大气参数波动对临近空间飞行热环境的影响
}

陈闽慷 ${ }^{1,2}$, 杜涛 $2^{*}$, 胡雄 ${ }^{3}$, 肖存英 ${ }^{3}$, 余梦伦 ${ }^{2}$, 田继超 ${ }^{2}$, 汤国建 ${ }^{1}$

1. 国防科学技术大学航天科学与工程学院, 长沙 410073;

2. 北京宇航系统工程研究所, 北京 100076;

3. 中国科学院国家空间科学中心, 北京 100190

*联系人, E-mail: dutao_calt@yahoo.com

2016-02-16 收稿, 2016-05-03 修回, 2016-05-03 接受, 2016-11-30 网络版发表

国家重点研发计划(2016YFB0501503)和国家自然科学基金(41104099)资助

摘要真实的大气参数随时间和地理位置变化, 而且有随机性的大气波动叠加, 处于波动状态, 造成高超飞行 器大气层飞行面临的真实热环境, 远比标准大气模型预测结果复杂得多. 在 $70 \mathrm{~km}$ 以上大气参数变化尤其复杂。 本文利用美国TIMED卫星在2002 2010年8年间对北半球典型纬度地区上空 $85 \mathrm{~km}$ 高度大气参数在典型月份期间内 的实测统计结果, 开展了大气参数分布特性对飞行器热环境具有代表性的驻点热流的影响研究. 研究发现大气的 波动对高超飞行的热环境有着重要和复杂的影响。同纬度地区4月或7月的热流会偏大，在同一季节，高纬度地区 的热流分布往往会大于低纬度地区. 在极端情况下，热流会比标准大气参数模型预测的热流高40\%以上.

关键词大气动力学, 大气模型, 气动热环境, 高超飞行器, 临近空间

随着高超声速技术的发展，越来越多的飞行任 务将在临近空间进行. 然而处于50 120 km高度范围 之间的大气，一直被学术界形象地称为“未知之层” (ignorosphere) ${ }^{[1]}$, 因为这一范围对于气球探空观察来 说太高, 相对于卫星平台探测来说又太低. 飞行器设 计中通常使用的标准大气模型随高度平滑变化, 且 不考虑地理位置和季节的影响 ${ }^{[2]}$, 实际的大气远比标 准大气模型复杂, 鲜有这么好的情况, 尤其在高空领 域会受纬度、经度和季节等多重因素的影响随时间 波动.

传统的弹道式或半弹道式的钝体再人飞行器(例 如战略弹头、宇宙飞船等) 通常是快速穿越这段高度 范围, 飞行时间短, 大气参数的波动对飞行任务的影 响并不显著. 而以航天飞机为代表的升力式再人飞 行器, 升阻比高, 在临近空间长时间滑翔飞行的累积 效应使得大气参数的波动对飞行任务有着不可忽略
的重要影响. 航天飞机研制初期, NASA也试图研究 大气参数波动对飞行任务的影响, 但是受限于当时 的技术能力, 成果有限 ${ }^{[3]}$. 认识更多来自航天飞机的 再人飞行遥测结果. 在多次飞行中均发现大气密度 的波动导致飞行阻力在连续几秒时间内突然变化高 达 $19 \%$, 而气动阻力是制导跟踪的重要指标, 造成攻 角频繁地来回波动，这是航天飞机的首批飞行遥测 结果中令人吃惊的现象之一 ${ }^{[4]}$. 大气参数波动相应也 会恶化飞行热环境. NASA在新高超飞行器的设计中, 会利用全球参考大气模型 $(\mathrm{GRAM})^{[5]}$, 评估大气参数 波动对飞行任务的影响 ${ }^{[3]}$. 但是NASA约翰逊中心的 专家研究发现 ${ }^{[4]}$, GRAM模型与航天飞机的再人飞行 遥测数据并不吻合, GRAM-95模型本身也吸收了航 天飞机的 22 次飞行获得的数据, 因此他们认为大气 参数波动对飞行的影响还需要开展更加深人的研究 工作. 目前, 我国还缺乏大范围区域大气参数波动对

引用格式: 陈闽慷, 杜涛, 胡雄, 等. 北半球高空大气参数波动对临近空间飞行热环境的影响. 科学通报, 2017, 62: 1402-1409 Chen M K, Du T, Hu X, et al. Effect of atmosphere parameter oscillation at high altitude in the northern hemisphere for near space hypersonic flight aerothermodynamic prediction (in Chinese). Chin Sci Bull, 2017, 62: 1402-1409, doi: 10.1360/N972016-00194 
高超飞行器临近空间飞行环境的影响研究, 因此这 一研究对于理论和工程实践都有重要的意义. 随着 技术手段的发展, 获取大气参数的手段多样化, 数据 也越来越充裕, 在飞行遥测的单次经验性认识之外, 为深人研究这一领域提供了必要条件.

在本文中, 选取 $85 \mathrm{~km}$ 高度的大气作为研究对象, 利用美国TIMED卫星SABER探测器的观察数据, 北 半球典型纬度地区和典型月份期间内近 100 个月的统 计结果作为真实大气模型, 研究纬度和季节变化对 临近空间飞行器气动加热的影响.

\section{1 高空真实大气参数的获取}

TIMED(thermosphere ionosphere mesosphere energetics and dynamics)卫星是一个美国科学卫星, 于 2001 年 12 月 7 日发射升空, 从2002年1月 22 日其载荷 SABER(sounding of the atmosphere using broadband emission radiometry) 开始获取观测数据. SABER是一 个10通道宽带辐射计, 在TIMED卫星沿轨道飞行过 程中, 采用临边测量 $\mathrm{CO}_{2}$ 的红外辐射获取从低平流层 到低热层大气的垂直剖面. TIMED卫星轨道高度 625 $\mathrm{km}$, 倾角 $74.1^{\circ}$, 轨道周期为 $1.6 \mathrm{~h}$. SABER数据在经 圈方向基本均匀分布; 由于 $S A B E R$ 每 60 天需要更换 一次临边探测的方向, 所以其纬度覆盖在 $\left(52^{\circ} \mathrm{S}\right.$, $\left.83^{\circ} \mathrm{N}\right)$ 和 $\left(83^{\circ} \mathrm{S}, 52^{\circ} \mathrm{N}\right)$ 之间转换.

本研究中选用V1.07版本的TIMED/SABER温度 和密度观测数据. 该数据已经得到多方面的验证 ${ }^{[6,7]}$. Remsberg等人 ${ }^{[6]}$ 指出, 与Envisat卫星上的MIPAS (michelson interferometer for passive atmospheric sounding)温度数据、英国气象局的分析资料、地基瑞 利激光雷达资料相比, SABER温度在低平流层高1 3 $\mathrm{K}$, 在平流层顶附近低约 $1 \mathrm{~K}$, 在中间层中部低约 $2 \mathrm{~K}$; 在中间层上部, SABER温度大体上比瑞利激光雷达 的观测温度低, 其偏差是变化的, 但与美国URAS卫 星上HALOE(Halogen Occultation Experiment)温度的 平均偏差接近于 0 ; 在低热层, SABER温度剖面与地 基测量的 $\mathrm{OH}$ 和 $\mathrm{O}_{2}$ 辐射反演的温度及钠多普勒激光雷 达的温度测量结果一致. SABER数据目前已大量应 用于中高层大气科学研究中.

本文收集从 2002年1月 2010年2月共98个月份的 观测资料, 数据内容包含: 纬度、经度、太阳地方时、 几何高度、温度和密度等, 用于大气波对飞行热环境 影响的研究.

\section{2 高空大气的统计分布}

大气参数在高空区域变化复杂, 会随纬度、经 度、高度、季节等因素而变化, 存在几分钟到 10 多天 的周期大气波(重力波、潮汐波和行星波等)活动现象, 并受大气湍流影响. 密度在时间和空间分布上呈现 随机性, 甚至空洞化. 大气参数总的变化包括系统分 量和随机分量. 随机分量的确定非常困难. 从高超飞 行任务上来看, 更关心大气参数相对标准大气模型 的偏差分布对气动力和气动热预测的影响.

大气温度和密度以 8 年中卫星探测数据为样本, 按月份作统计处理, 分析大气温度平均值、标准偏 差、在统计样本范围内最大值和最小值的分布. 标准 大气模型选择高超声速飞行器设计上通常采用的美 国标准大气-1976年模型 ${ }^{[2]}$.

60 100 km 的大气包含中间层、中间层顶和低热 层. 由于大气密度越来越稀薄, 上传的大气重力波在 该高度范围内振幅变大、易发生饱和破碎现象, 引起 局部不稳定过程、激发湍流; 大气潮汐波在70 $\mathrm{km}$ 以 上变得越来越显著; 大气瞬态行星波活动常年存在, 并对大气重力波和潮汐波活动产生调制作用; 这些 大气波动具有明显的地理位置、季节变化特征. 由于 $85 \mathrm{~km}$ 高度上大气重力波、潮汐波和行星波活动都较 为显著, 而且属于过渡流区域, 因此在本文研究中, 选取了 $85 \mathrm{~km}$ 高度作为研究对象, 经度为东经 $110^{\circ}$, 纬度选择了北半球 5 个典型区域: 北纬 $0^{\circ}, 20^{\circ}, 40^{\circ}$, $60^{\circ}, 80^{\circ}$. 在上述区域一年当中代表一年四季的 4 个 典型月份 1 月、 4 月、 7 月和 10 月的大气参数作为研究 对象. 研究结果可以揭示纬度和季节引起的大气参 数变化对热环境的影响. 在统计过程中, 我们对卫星 原始数据进行了野值剔除等质量控制.

图1(a)和(b)分别给出了 $85 \mathrm{~km}$ 高空7月大气温度 和大气密度随纬度变化的统计分布结果作为例子, 在图中并与标准大气模型进行了比较.

\section{3 驻点热流的预测方法}

在飞行器的热流分布上, 飞行器端头驻点处的热 流具有典型的代表性. 因为驻点处热流受其他因素干 扰比较小, 试验和计算均可提供相对准确可靠的结果. 高超飞行器设计上, 驻点热流的大小可以为其他位置 处热流的评估和预测提供参考. 考察驻点热流随大气 偏差的变化情况基本可以刻画出真实大气偏离 

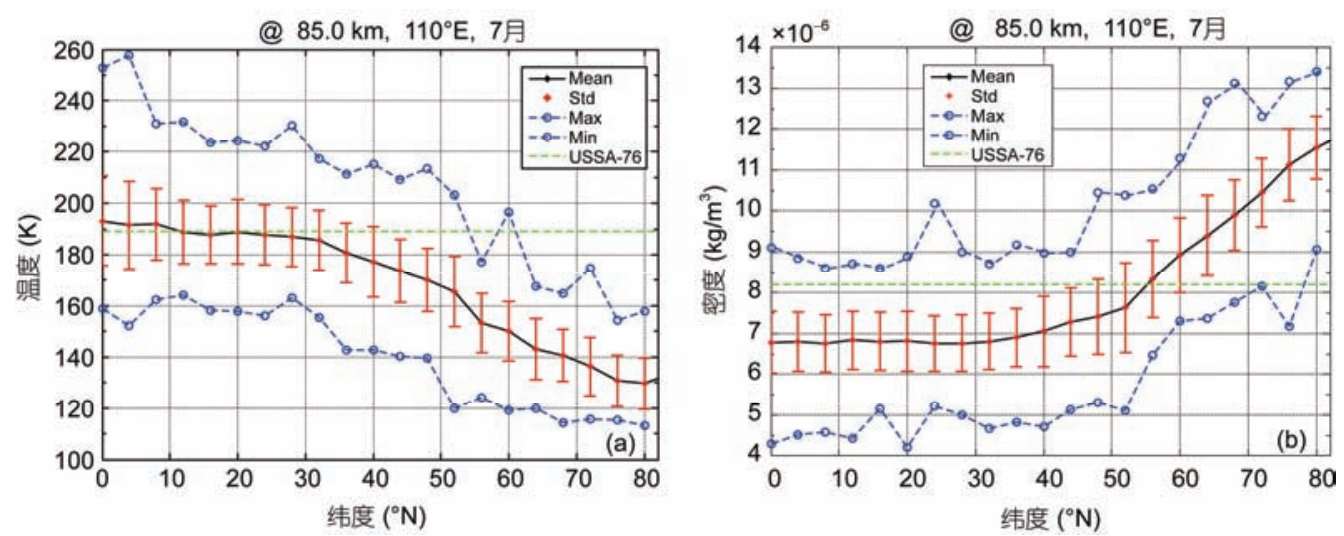

图 1 (网络版彩色) $85 \mathrm{~km}$ 高空 7 月大气温度(a)和大气密度(b)随纬度变化

Figure 1 (Color online) Atmosphere temperture (a) and desinity (b) in $85 \mathrm{~km}$ altitude according latitudes

标准大气模型对整个飞行器表面气动热环境的影响.

本文采用在高超飞行器设计上广泛应用的 Fay-Riddell公式作为驻点热流的预测方法 ${ }^{[8]}$. 需要说 明的是, 本文不研究预测方法本身的适应性和预测 结果同真实热流的偏差问题, 相关研究可参见文 献[9 11]. 在本文中, 选取端头驻点半径为 $40 \mathrm{~mm}$, 来流速度为 $6000 \mathrm{~m} / \mathrm{s}$, 飞行高度为 $85 \mathrm{~km}$ 作为研究对 象. 图2提供了Fay-Riddell公式在该条件下的适应性 分析, 横坐标为 Cheng参数 ${ }^{[12]}$, 纵坐标是无量刚热流 斯坦顿数St, 文献[9]对Cheng参数的正确性进行了理 论分析. 从图中可以看到在该条件下Fay-Riddell公式 提供的结果与DSMC(direct simulation Monte Carlo) 方法模拟得到的驻点热流一致, 同时与风洞试验数据

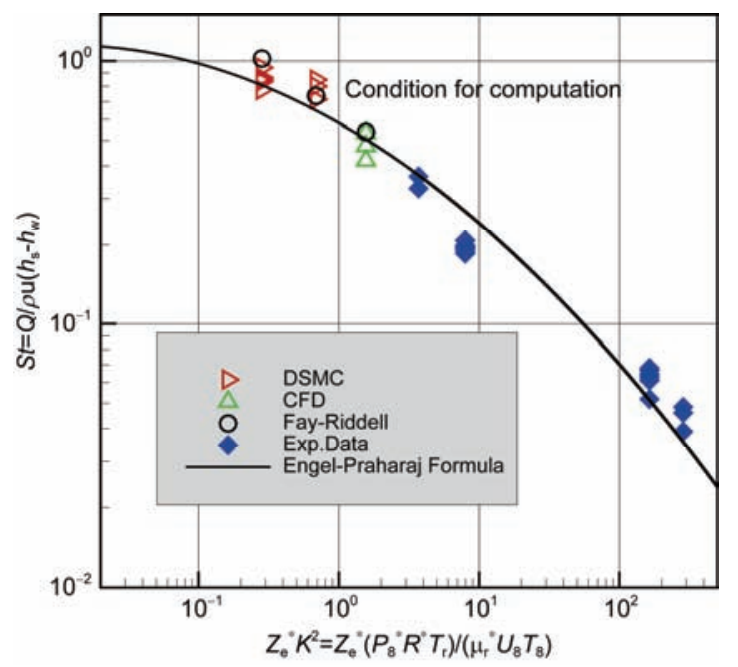

图 2 (网络版彩色)Fay-Riddell公式的适应性分析

Figure 2 (Color online) The adaptability analysis for Fay-Riddell Formula
一致性符合Engel-Praharaj公式 ${ }^{[13]}$ 的分布. Engel-Praharaj 公式是NASA在长期工程实践中, 在大量试验数据基础 上拟合出来的热流预测公式. 因此, 可以认为该条件 下Fay-Riddell公式预测的驻点热流是可信的.

利用两个无关的随机函数分别产生满足特定范 围和分布特征要求的大气参数温度和密度子样. 分 析中每一分布包含 5000 个子样. 随机函数分别采用 了两种分布特征：一种是当月温度和密度最大最小 值区间之间的均匀分布，另外一种是满足均方差的 当月的正态分布. 图3中给出了某次分析中所有子样 的分布特征. 图3(a)和(b)分别是温度分布和密度分 布. 空心柱图表示正态分布, 实心细柱图表示均匀分 布. 纵坐标是子样的次数, 表示在 5000 个子样中, 子 样在该温度(或密度)区间内出现的次数.

\section{4 结果分析}

热流结果也同样用类似的统计直方图分析. 每一 分布所有子样计算得到对应的热流, 以组距为 10 $\mathrm{kW} / \mathrm{m}^{2}$ 的区间间隔统计出现的频数, 算出对应频率. 由 于采样次数足够大, 得到的频率接近分布概率. 一般 来说, 结果的直方图外轮廓曲线接近于热流分布的概 率密度曲线. 同时采用美国1976年标准大气模型在该 条件下的热流为参考值无量刚化每一子样的热流值. 这样处理的优点是, 结果具有普适性, 无量纲值的分 布特征同来流速度和端头半径的尺寸是无关的，只同 大气参数的波动特性相关. 同时结果也更直观, 无量 刚化后以 1 为界, 大于 1 和小于 1 可以清楚显示出真实大 气子样分布同标准大气模型热流的大小关系和偏离程 度. 另外需要指出的是, 本文的分析虽然只是针对驻 

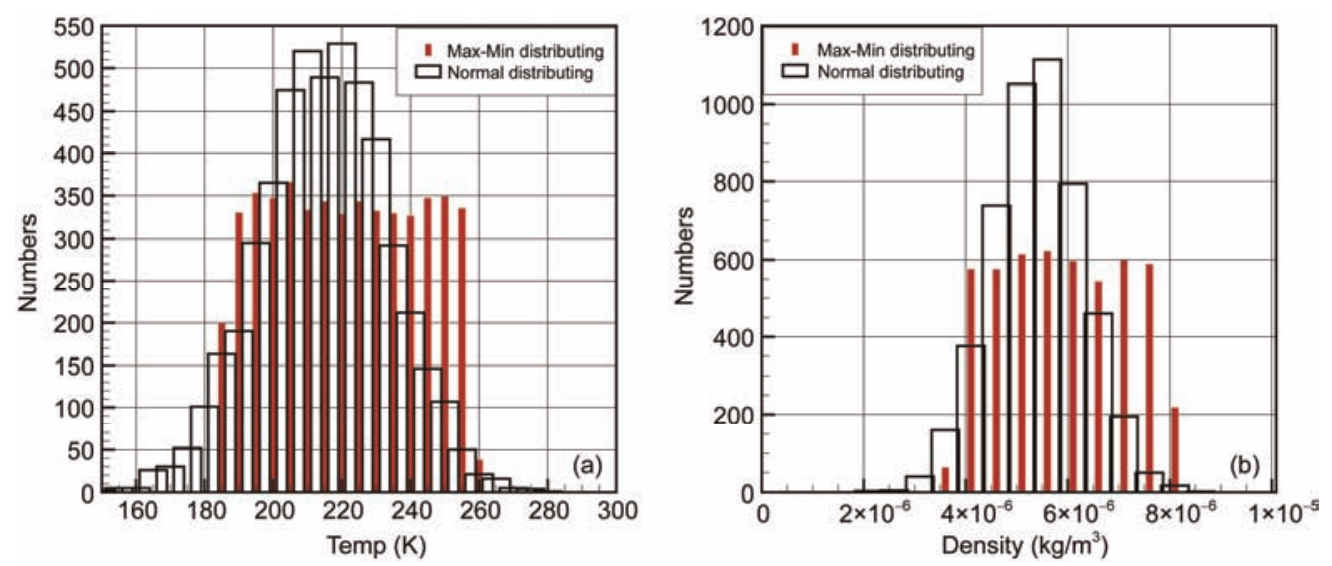

图 3 (网络版彩色)温度(a)和密度(b)随机子样分布直方图

Figure 3 (Color online) The temperture (a) and density (b) random samples distribution histogram

点区域, 但是结论也适用于飞行器其他部位, 在飞行 器其他部位的热环境的预测中也是需要同样考虑.

图4依次给出了 $85 \mathrm{~km}$ 高空北纬 $0^{\circ}, 20^{\circ}, 40^{\circ}, 60^{\circ}$, $80^{\circ}$ 区域在代表一年四季的 4 个典型月份 1 月、4月、7 月和 10 月内, 利用卫星测量得到的当月最大-最小均 匀分布和正态分布大气参数下, 热流的分布规律. 每 一横行的纬度相同, 每一纵行的月份相同. 其中 4 月 份, 只获得了北纬 $48^{\circ}$ 以内的大气数据. 这是因为, TIMED/SABER卫星在该月没有北纬 $52^{\circ}$ 以北的观测 数据. 从图中可以看到, 季节和纬度变化对热流的分 布规律有着复杂的影响, 标准大气模型是不足以反 映和覆盖纬度和季节性变化对热流分布影响的复杂 性. 没有一个月份的正态分布期望正好位于标准大 气模型的热流处或是附近. 极端情况下热流可能超 过标准大气模型热流 $30 \%$ (北纬 $80^{\circ}$ 地区7月), 也可能 比标准大气模型热流低 $40 \%$ (北纬 $60^{\circ}$ 或 $80^{\circ}$ 地区 1 月).

下面我们分别分析季节和纬度对热流分布规律 的影响.

\section{1 季节因素分析}

在同一纬度区域, 最大热流均出现在 4 月和 7 月, 可见季节因素对热流的影响是一致的. 不过不同纬 度, 季节因素对热流的影响程度不一样, 高纬度地区 季节因素对热流的影响非常显著. 以北纬 $80^{\circ}$ 区域的 结果为例, 7月份热流分布全部超过标准大气模型, 而其他季节热流均主要分布在小于标准模型气动热 区域. 7月的正态分布的期望接近 $1.2,1$ 月份的正态期 望只有 0.8 . 北纬 $60^{\circ}$ 区域的结果也是类似. 相反在低
纬度区域, 季节因素对热流分布的影响就比较小, 北 纬 $0^{\circ}$ 和 $20^{\circ}$ 区域的热流分布位置和形态相似, 几乎不 随季节因素而发生变化. 以北纬 $0^{\circ}$ 为例, 除了 1 月的 正态分布的期望在 0.93 附近, 其余月份均在 0.9 附近, 相互之间的差别非常小. 有区别的是7月份的散布相 对比较大一些. 北纬 $20^{\circ}$ 地区最为显著, 其余月份正 态分布期望的概论接近 0.15 , 而 7 月份正态分布期望 的概论只有不足 0.11 . 最大-最小值分布的区间范围 明显更大. 表明7月份的低纬度地区高空大气参数的 波动范围更大更剧烈. 而在高纬度地区, 这一趋势正 好相反，7月份的热流分布集中，而其余月份的热流 分布更加离散. 这种大范围内的波动特性发生的时 间尺度是飞行器设计上非常关心的, 如果是在短时 间内高频率发生, 将会对飞行器的控制和热环境都 有重要的影响, 后续需要进一步深人的分析.

\section{2 纬度因素分析}

纬度因素对热流分布的影响, 以7月份最为显著, 无论是正态分布统计还是最大-最小热流均匀分布统 计, 均是纬度越高, 热流分布越大, 最大热流出现在 北纬 $80^{\circ}$ 区域. 其他月份的规律比较复杂. 以冬季 1 月 份为例, 正态统计期望的最大值出现在北纬 $0^{\circ}$ 和 $20^{\circ}$ 区域, 而北纬 $80^{\circ}$ 的正态分布的期望值最小, 但是最 大最小分布的最大值出现在北纬 $60^{\circ}$ 区域. 秋季 10 月 份的结果也与此类似. 上述结果对于飞行任务的热 环境分析和飞行弹道的选择有着指导作用.

另外需要指出的是 7 月份在北纬 $80^{\circ}$ 地区的热流 显著高于其他纬度和月份. 正态分布期望值位于 1.18 

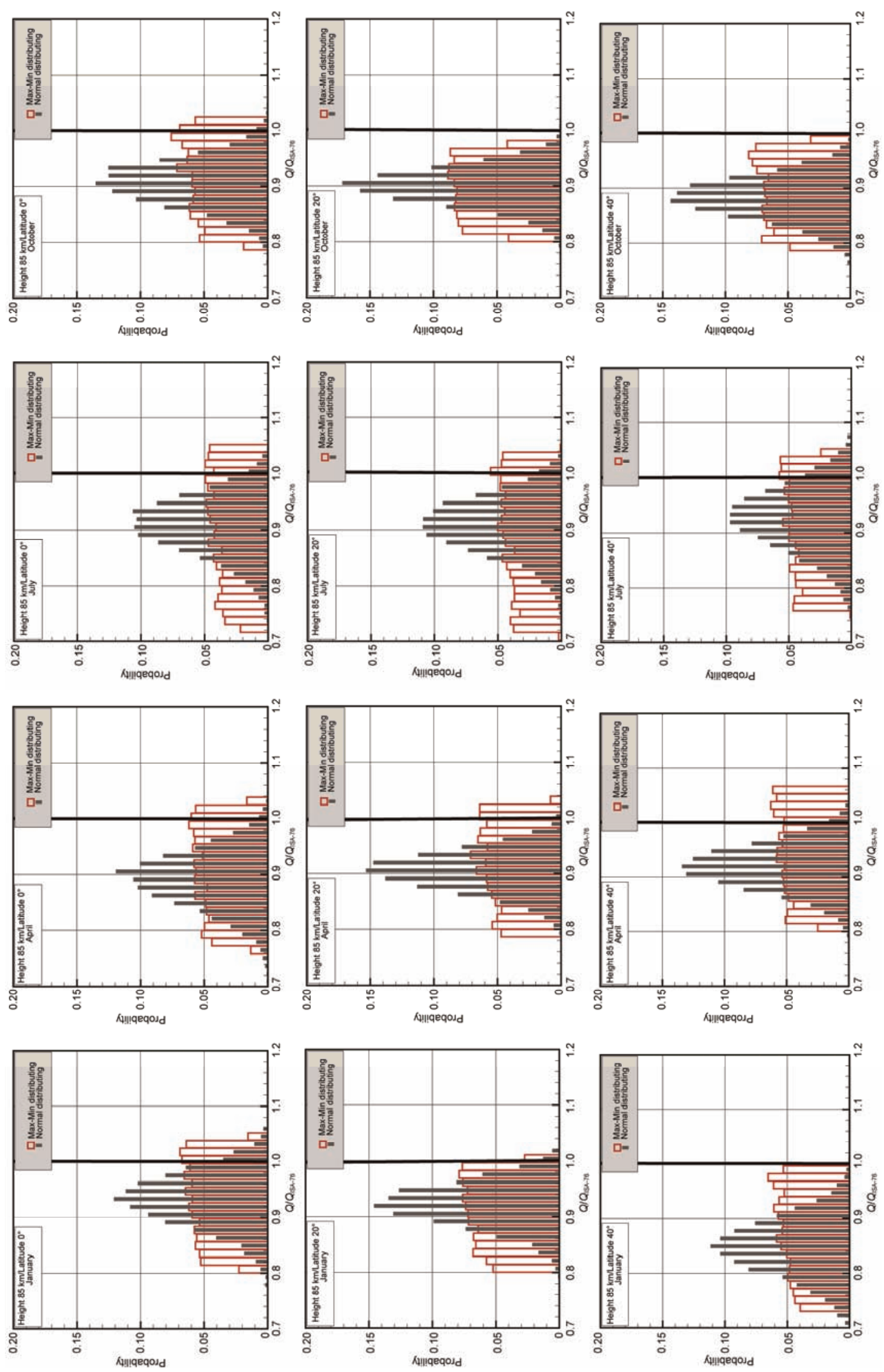

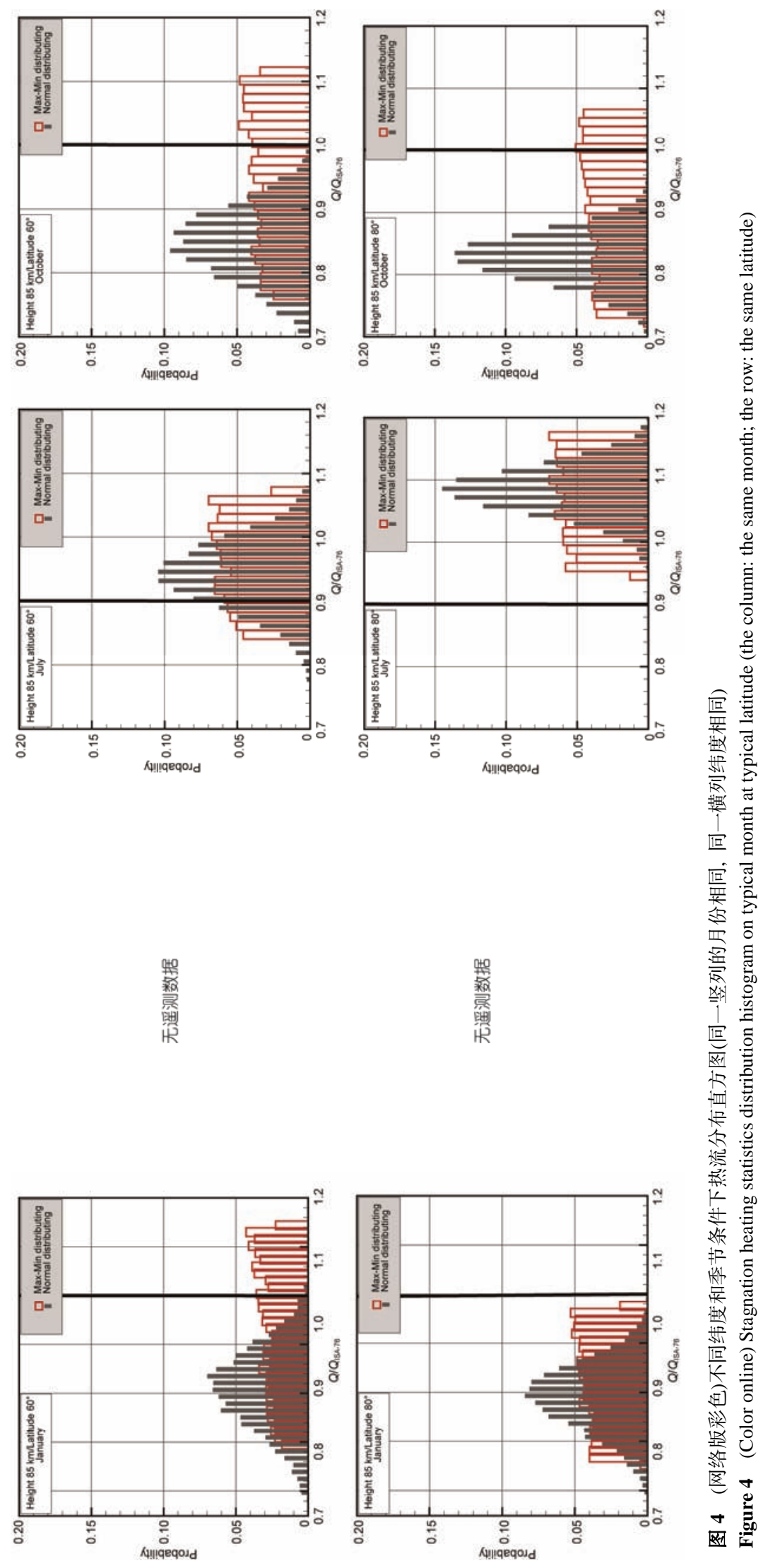
附近, 而最大最小分布得到的热流全部超过 1.0. 这 表明飞行器夏季在高纬度地区上空再入时候, 由于 大气参数的波动, 飞行器的整体气动加热水平将高 于标准大气模型给出的结果, 这对飞行器的飞行热 环境是非常不利的. 这一结论与美国航天飞机轨道 级不允许夏季从北极上空再人的禁令是一致的 ${ }^{[4]}$.

上述统计结果可以从理论上得到解释. 临近空 间大气的基本物理过程主要包括: 大气动力学、辐射 和光化学平衡等. 在 $85 \mathrm{~km}$ 高度的中间层顶区域, 由 于大气动力学过程的影响, 主要是由于低层大气产 生的大气重力波携带动量和能量上传, 在该区域发 生饱和破碎, 严重影响大气环流状态, 导致大气温 度严重偏离辐射和光化学平衡状态; 由于赤道地区 动力学与中高纬度地区动力学的差异, 在赤道低纬 度地区, $85 \mathrm{~km}$ 附近呈现明显的半年周期振荡, 而中 高纬度地区则出现显著的周年振荡, 即出现冬暖夏 凉的现象 ${ }^{[14,15]}$. 冬季中高纬度地区, 大气参数的标 准偏差较大、极值变化幅度大, 可能与冬季极区平
流层爆发性增温极端现象、以及地形重力波上传等 有关.

\section{5 结论}

本文开展了利用TIMED卫星2002 2010年实测 $85 \mathrm{~km}$ 高度大气参数的逐月统计结果, 分析了典型月 份和典型纬度大气参数波动对气动热环境预测的影 响. 分析发现大气的波动对高超飞行的热环境有着 重要和复杂的影响. 同纬度地区4月或7月的热流会 偏大，1月和 10 月的热流分布会向左端移动. 在同一 季节, 高纬度地区的热流分布往往会大于低纬度地 区. 在低纬度地区，热流分布普遍低于标准大气模型 结果, 在高纬度地区, 热流分布往往高于标准大气模 型的结果. 在极端情况下, 热流会比标准大气参数模 型的热流高 $40 \%$ 以上. 在后续的研究中, 将开展 60 100 km高度的更大范围大气、南北半球差异、经 度变化、地面海洋和陆地区域以及大气参数相关性对 高超飞行器气动加热的影响.

\section{参考文献}

1 Qin Z L, Zhu B Y, Lü F C, et al. Using time domain waveforms of return strokes to retrieve the daytime fluctuation of ionospheric D layer (in Chinese). Chin Sci Bull, 2015, 60: 654-663 [秦子龙，祝宝友，吕凡超，等 利用雷暴闪电事件监测电离层 D层日间波动. 科 学通报, 2015, 60: 654-663]

2 National Oceanic and Atmospheric Administration, National Aeronautics and Space Administration, United States Air Force. U.S. Standard Atmosphere, 1976. Technical Report, 1976. NASA-TM-X-74335

3 Dale L, Barry C, William W, et al. Atmospheric models for engineering applications. In: Proceedings of the 41st Aerospace Sciences Meeting and Exhibit. Reno: AIAA, 2003, AIAA 2003-894

4 Hale N, Jr Lamotte N, Garner T. Operational experience with hypersonic entry of the space shuttle. In: The Proceedings of AIAA/AAAF 11th International Space Planes and Hypersonic Systems and Technologies Conference. Orleans: AIAA, 2002. AIAA-2002-5259

5 Justus C, Jeffries III W, Yung S P, et al. The NASA/MSFC Global Reference Atmospheric Model-1995 Version (GRAM-95). 1995, NASA TM-4715

6 Remsberg E, Marshall B, Garcia-Comas M, et al. Assessment of the quality of the Version 1.07 temperature-versus-pressure profiles of the middle atmosphere from TIMED/SABER. J Geophys Res, 2008, 113: 1641-1653

7 Garcia-Comas M, López-Puertas M, Marshall B T, et al. Errors in Sounding of the Atmosphere using Broadband Emission Radiometry (SABER) kinetic temperature caused by non-local-thermodynamic-equilibrium model parameters. J Geophys Res, 2008, 113: 1143-1156

8 Fay J, Riddell F. Theory of stagnation point heat transfer in dissociated air. J Aeronaut Sci, 1958, 25: 73-85

9 Wang Z H, Bao L, Tong B G. Variation character of stagnation point heat flux for hypersonic pointed bodies from continuum to rarefied flow states and its bridge function study (in Chinese). Sci China Ser G Phys Mech Astron, 2009, 39: 1134-1140 [王智慧, 鲍麟, 童秉纲. 高超声速尖头体驻 点热流从连续态过渡到稀薄态的变化特征和桥函数研究. 中国科学 $\mathrm{G}$ 辑: 物理学 力学 天文学, 2009, 39: 1134-1140]

10 James N, Vincent C, Simmonds A. Nonequilibrium effects for hypersonic transitional flows. In: The Proceedings of 25th AIAA Aerospace Sciences Meeting. Reno: AIAA, 1987. AIAA 87-0404

11 Wang W, Boyd I. Continuum breakdown in hypersonic viscous flows. In: Proceedings of the 40th AIAA Aerospace Sciences Meeting and Exhibit. Reno: AIAA, 2002. AIAA-2002-0651

12 Cheng H K. The blunt-body problem in hypersonic flow at low Reynolds number. Cornell Aeronautical Laboratory Report. 1963, AF1285-A-10

13 Engel C, Praharaj S. MINIVER upgrade for the AVID system. NASA, 1983. NASA-CR-172212

14 Andrew D, Holton J, Leovy C. Middle Atmosphere Dynamics. Florida: Academic Press, 1987

15 Ji R F. Disturbed atmosphere model (in Chinese). Space Entry Remote Sens, 1995, (1): 66-81 [季蓉芬. 地球扰动大气模型. 航天返回 与遥感, 1995, (1): 66-81] 


\title{
Effect of atmosphere parameter oscillation at high altitude in the northern hemisphere for near space hypersonic flight aerothermodynamic prediction
}

\author{
CHEN MinKang ${ }^{1,2}$, DU Tao $^{2 *}$, HU Xiong $^{3}$, XIAO CunYing $^{3}$, YU MengLun $^{2}$, TIAN JiChao $^{2} \&$ \\ TANG GuoJian ${ }^{1}$ \\ ${ }^{1}$ College of Aerospace Science and Engineering, National University of Defense Technology, Changsha 410073, China; \\ ${ }^{2}$ Beijing Institute of Astronautics System Engineering, Beijing 100076, China; \\ ${ }^{3}$ National Space Science Center, Chinese Academy of Sciences, Beijing 100190, China \\ * Corresponding author, E-mail: dutao_calt@yahoo.com
}

For real atmosphere parameter fluctuates from the standard atmosphere model according the time and geography with stochastic atmospheric wave, it is important to predict the deviation effect on the aerothermodynamics environment for gliding hypersonic vehicle. However, according to the experts at NASA Johnson Space Center, at present neither the standard atmosphere model or the reference atmospheric model is able to describe the complex real atmosphere accurately. Especially, above $70 \mathrm{~km}$ altitude, the atmosphere parameter varies complicatedly, and deviates from standard atmosphere model intensely. The measurement results of atmosphere parameter from SABER (Sounding of the Atmosphere using Broadband Emission Radiometry) on TIMED satellite, launched at 2001, are testified widely with data from other sources. In this paper, based on measurement results between 2002 and 2010 from SABER on TIMED satellite, the atmosphere parameter statistics characters for $85 \mathrm{~km}$ altitude in typical months (January, April, July and October) and typical northern latitudes $\left(0^{\circ}, 20^{\circ}, 40^{\circ}, 60^{\circ}, 80^{\circ}\right)$ are obtained. In every research case, over 5000 stochastic samples are produced, which are satisfied with Max-Min distributing or normal distributing for the atmosphere model. The heating transfer on stagnation for stochastic sample in the on-the-spot survey parameter has been also studied. Then the statistics characteristics of the heating transfer on stagnation can be obtained and compared with the results based on U.S.1976 standard atmosphere, which shows the atmosphere oscillation statistics effect. The effect for latitudes and seasons on aerothermodynamics prediction has been investigated. It is shown that fluctuation for the atmosphere parameter plays an important role on the aerothermodynamics environment in near space flight. In the high altitude zone, season factor has a notable effect on the heating distribution. However, close to the equator, season factor has a little effect. At the same reason, heating transfer in higher altitude zone is usually greater than that from the standard model; on the contrary, heating transfer in lower altitude zone is general lower than that from the standard model. In summer (July), the higher latitude zone locates, the higher heating distribution it gets. The maximum heating transfer appears in July on $80^{\circ}$ latitude. In extreme case, the maximum stagnation heating exceeds the result from the standard atmosphere model about $40 \%$. At the same altitude, the maximum heating transfer appears in April or July. In the future work, the affection about the difference between Northern and Southern Hemisphere, between ocean and land and atmosphere parameter relativity will be researched.

atmospheric dynamics, atmosphere model, aerothermodynamics, hypersonic vehicle, near space

doi: 10.1360/N972016-00194 